\title{
Futures Trading and Spot Market Volatility: Evidence from Indian Commodity Markets
}

\author{
Prof. Sanjay Sehgal \\ University of Delhi \\ E-mail: sanjayfin15@gmail.com \\ Dr. Namita Rajput \\ University of Delhi \\ E-mail: namitarajput27@gmail.com \\ Mr Rajeev Kumar Dua \\ CMJ University \\ E-mail: capt.rkd@gmail.com
}

Received: June 25, 2012

doi:10.5296/ajfa.v4i2.1990
Accepted: August 20, 2012 Published: December 1, 2012

URL: http://dx.doi.org/10.5296/ajfa.v4i2.1990

\begin{abstract}
In the context of emerging Indian commodity futures markets, this paper empirically examines the effect of futures trading activity (trading volume ; proxy of futures liquidity) on spot price volatility for seven agricultural commodities (guar seeds, turmeric, soya bean, black pepper, barley, Maize and Castor Seed).We decompose the futures volume into expected and unexpected components using Hodrick-Prescott filter (HP filter) .To clearly understand the destabilization effect, the relationship of the unexpected liquidity of futures market is done with Unexpected volatility of spot market returns which is estimated by taking the residuals of the GARCH model. We find that unexpected futures trading volume is Granger causing spot price volatility and are significant for five out of seven agricultural commodities (Guarseed, Turmeric, Soybean, Maize and Castor Seed), consistent with Bessembinder and Seguin (1992). We find reversed effect for one commodity i.e. Pepper the effect of spot volatility on futures trading and for Barley no causality is revealed either from
\end{abstract}


future to spot or Vice-Versa. Besides being of interest to the participants, this study is likely to be useful in addressing the concerns of policy makers in India on alleged destabilizing effect of futures markets on spot prices as for emerging futures markets. Commodity exchanges must be strengthen and put under strict and active monitoring for early detection of anomalous trading behaviour. Financial autonomy and adequate powers should be given to Forward Market Commission to penalise any insider trading and price manipulations, this will minimize price distortions. The Government support shall lead to market growth and overall economic development.

Keywords: Indian commodity futures markets, Expected and unexpected futures trading activity, Trading volume, Open interest, Spot volatility

JEL Codes: G10, G14, G15 


\section{Introduction}

The global liberalization and integration of financial markets has shaped new investment opportunities, which in turn require the development of new instruments that are more proficient to deal with the increased risks. Investors who are actively engaged in industrial and emerging markets need to hedge their risks from these internal as well as cross-border transactions. Agents in liberalized market economies who are exposed to volatile stock prices and interest rate changes entail suitable hedging products to pact with them. With the advent of liberalisation and economic expansion in these emerging economies demands that corporations should discover better ways to manage financial and commodity risks. The most wanted instruments that allow market participants to manage risk in the modern securities trading are known as derivatives which are a new advent in developing countries compared to developed countries. The main reason behind the derivatives trading is that derivatives reduce the risk by providing an additional way to invest with lesser trading cost and it facilitates the investors to extend their settlement through the future contracts. It provides extra liquidity in the stock market. They represent contracts whose payoff at expiration is determined by the price of the underlying asset - a currency, an interest rate, a commodity, or a stock. Derivatives are traded in organized stock exchanges or over the counter by derivatives dealers. The issue of the impact of derivatives trading on stock market volatility has received considerable attention in recent years in India, particularly after the stock market crash of 2001. Derivative products like futures and options on Indian stock markets have become important instruments of price discovery, portfolio diversification and risk hedging in recent times. In the last decade, many emerging and transition economies have started introducing derivative contracts. Since derivatives markets have been in existence form as long, and by many accounts even longer than that for securities, it has been their growth in the past 30 years that has made them a significant segment of the financial markets. The issue pertaining to the impact of index futures on the volatility of the fundamental spot market has increasingly received the awareness of researchers and policy makers alike. This is primarily due to the destabilizing perception surrounding index futures in the context of several stock market crashes, such as US market crash of 1987, the US flash crash in 2010, and the Indian stock market crash in 2008. Empirical researchers have tried to find a pattern in stock return movements or factors determining these movements. They believe that speculation is inherently unstable because of the herd tendency, selling at falling prices and buying at rising prices thereby escalating the amplitude of volatility of spot prices. The effect of futures trading on cash price volatility has long been discussed.

Commodity futures trading in India has been an issue of hot debate amongst policy makers and academics. It has also caught strong media attention in the past few years; owing to fears of price manipulations and the general belief that possible speculative trading in futures market may have destabilised spot prices of underlying commodities. Proponents of commodity futures derivative trading assert that these markets help in price discovery of underlying physical commodities and provide risk management platforms for hedgers such as farmers, industrial units, exporters, importers, etc., who have price risk exposures. Commodity futures trading have played an important role in economic development because 
of its eco-system linkages and role in employment generation. These trading platforms have also helped in integrating Indian markets with the world markets, thus, reducing any price distortions. Since India is one of the largest consumer as well as producer of many agri commodities, time is ripe for India to take a price leadership role at international level. However, some concerns have been raised, off and on, about the possible insider-trading and price rigging, especially in futures trading of agri-commodities. They believe that these insider traders might have worked as cartels to unduly influence the prices and make huge profits in the process. Thus, it is important to empirically examine the price and trading behaviour of agri-commodities in order to suggest measures for strengthening these markets. We specially focus on seven commodities, i.e., Guar Seeds, Turmeric, Soya Bean Black Pepper, Barley, Maize and Castor Seeds.

The objective of the Study is to examine the stabilizing/de-stabilizing effect of derivatives market on spot market for seven agricultural commodities mentioned above. As far as empirical research is concerned, evidence on stabilizing/de-stabilizing effect of derivatives market on spot market is far from conclusive. It is interesting to investigate the issues empirically in emerging markets like Indian commodity futures markets. Besides being of interest to the participants, it is likely to be useful in addressing the concerns of policy makers in India on alleged destabilizing effect of futures markets on spot prices. Emerging futures markets typically have different characteristics. According to Bakaert and Harvey (1997) and Antoniou and Ergul (1997), emerging futures market are characterized by low liquidity, thin trading, and consequentially returns exhibit higher sample averages, low correlations with developed market returns, non-normality, better predictability, higher volatility, and offer smaller samples for empirical research. It is usually assumed that the emerging market exhibit higher price variability and poor information processing (Tomek, 1980; Carter, 1989). Poor flow of information and higher volatility may affect the spot prices. In this paper, we empirically investigate the effect of futures trading activity on spot markets. The paper is organized as follows. Section 2 presents the data and basic characteristics of spot returns and futures trading activity. In Section 3, describes the models used in the study and the results are presented in Section 4 and section 5 concludes and references are contained in the last section.

\section{Review of Literature}

The stabilization issue involves the study of the spot price volatility behaviour. If derivative trading does improve the information transmission efficiency, the volatility clustering behaviour in spot price volatility will be narrowed. The speculative forces attracted by the lower transaction cost feature in derivatives may intense spot price volatility and increase information transmission from derivatives to spot markets. Therefore it may be reported that the introduction of derivatives trading significantly affects the volatility of the underlying spot market. This has been a major source of concern for both fund managers and regulators. As a corollary, the impact of derivatives trading on the volatility of the underlying spot market is intensely debated. There are diverse viewpoints relating to stabilisation and destabilisation in spot market prices because of derivative trading. 
There are many studies which talk about this that futures trading may de-stabilize the spot market by making them more volatile (Cox, 1979; Figlewski, 1981; Clifton; 1985; Grammatikos and Saunders, 1986; McCarthy and Najand, 1993; Chatrath et al., 1996).On the other hand there is a divergent view on this stating that derivatives market stabilizes the spot market (Danthine, 1978; Kyle's, 1985, and Froot and Perold, 1991).Morgan (1999) concluded that the level of inventories held in the spot market will be determined by the basis and will ensure a more efficient process of private storage, which in turn, ensures a smoother pattern of prices in the spot market hence stabilise the market. The empirical findings significantly shows that comparative advantage of futures market in disseminating information, leading to a significant price discovery and risk management, that can again help to successfully develop the underlying commodity market in India. Therefore instead of curbing the commodity futures market, it can always be suggested to strengthen the market structure to achieve the broader target, hence is instrumental in improving market efficiency by capturing the expected demand supply shock in the spot market through hedging in futures market. This process will help in stabilizing spot market volatility.

The issue of stabilization /Destabilization effect of futures trading on spot market can be grouped into two categories- (1) Examining the spot volatility before and after the introduction of futures (Antoniou et al, 1998; Lee \& Ohk, 1992), (b) Probing the connections between futures trading activity (trading volume and open interest) and spot volatility (Bessembinder \& Seguin, 1992; Gulen and Mayhew, 2000; Board et al, 2001). A number of studies in equity, commodity and currency futures markets provide the empirical evidence on de-stabilizing effect of futures trading on spot market. In equity market, many studies (Harris, 1989; Damodaran, 1990; Lockwood and Linn, 1990; Schwert, 1990; Chang, Cheng, and Pinegar, 1999; Kyriacou and Sarno, 1999) have found a positive relationship between futures trading activity and spot price volatility in US, UK and other developed markets. On the contrary, some studies (Santoni, 1987; Bessembinder and Seguin, 1992; Brown-Hruska and Kuserk; 1995) found that futures trading activity negatively affects the spot volatility. Bessembinder and Seguin (1992) there was a division of the trading volume and open interest into two components i.e expected and unexpected component and establish that stock price volatility is positively associated to unexpected trading activity, but negatively associated to expected component of trading activity. Chang et al. (2000) decomposed spot volatility estimates into expected and unexpected components and found that hedging activity in futures increases when unexpected volatility increases but speculative activity is not pretentious by the volatility. In currency market, Clifton (1985), Chatrath (1996), Grammatikos and Saunders (1986) and McCarthy and Najand (1993) positive correlation was found between spot price variability and volume of futures trading. However, Adrangi and Chatrath (1998) and Sarwar (2003) establish stabilizing effect of futures trading on currency market.

In commodity futures markets, few studies have addressed this issue. Pashigian (1986) and Weaver and Banerjee (1990) opined that futures trading activity destabilizes the spot volatility of agricultural commodities. In a review paper, Kamara (1982) explicate that in the majority of the empirical studies relating to agricultural derivatives market it was found that the introduction of futures trading normally condensed or at least did not increase the spot price 
volatility. In a study done by Yang et al. (2005) it was examined that the dynamic relationship between futures trading activity and spot volatility for agricultural commodities found that any increase in unexpected futures trading volume unidirectional causes an increase in the spot price volatility for most of the agricultural commodities. A weak causal relationship between open interest and the spot volatility was found in the study.

Methodologically, most of the studies pertaining to the empirical test of stabilizing/destabilizing effect of derivatives market on spot market with a focus on the impact of introduction of futures trading compare spot price volatility before and after the introduction of futures trading. Studies in this area model time varying volatility as GARCH process. Other approach used in the literature (Bessembinder and Seguin, 1992) is estimation of contemporaneous relationship between trading activity (trading volume and open interest) and spot volatility. In this approach, spot price volatility is estimated as a GARCH process. The effect of futures trading activity on spot volatility is investigated through augmented GARCH model in which trading activity is used as exogenous variable. Futures trading volume and open interest are then divided into expected and unexpected components and effect of expected and unexpected part of trading activity on spot volatility is examined. The dynamic relationship between spot volatility and futures trading activity is also examined through Vector Autoregressive specifications. Most of these have been in the context of equity (index futures) and currency markets, and very few studies (Pashigian, 1986; Weaver and Banerjee, 1990, and Yang et al., 2005) have investigated this issue empirically in the context of commodity futures market. Sen and Paul (2010) have clearly suggested that future trading in agricultural goods and especially in food items has neither resulted in price discovery nor less of volatility in food prices. They observed a steep increase in spot prices for major food items along with a granger causal link from future to spot prices for commodities on which futures are traded.

In emerging commodity derivatives markets the issue of volatility has not been researched sufficiently owing to features of markets like emaciated in terms of volume and number of derivatives products and in terms of participation also it is very limited. Emerging commodity markets in general and India in particular are generally disparaged for speculative activity and destabilizing role of derivatives in spot market through increased price volatility. This is evident from the action of government of India that many a time's agricultural commodities have been banned for their assumed destabilizing effect on spot market. The commodity derivatives markets in India is also facing increased ruling on futures trading regardless of any reliable empirical evidence in this regard. Most of these have been in the context of equity (index futures) and currency markets, and very few studies (Pashigian, 1986; Weaver and Banerjee, 1990, and Yang et al., 2005) have investigated this issue empirically in the context of commodity futures market. This study seeks to address these research gaps by investigating the issues of stabilizing/destabilizing effect of futures activity on spot market in Indian commodity futures market context. In this study, we analyze few agricultural commodities in detail which will help in understanding the relationships between futures trading activity and spot market volatility for agricultural commodities. 


\section{Data and Methodology}

Our data set in the study consists of seven commodities namely guar seeds, turmeric, soybean black pepper, barley, Maize and castor seed which are most actively traded on National Commodity Exchange (NCDEX). The selection of agricultural commodities have been done because of the fact that there are serious issues relating to these inflationary pressures and are also in lime light owing to policy debates especially on agricultural commodities. Essential commodities like Wheat and Rice are not a part of the sample as structured time series data relating to these commodities was not available as they were banned because of inflationary tendencies and rest of the sample commodities are highly traded commodities on the exchange hence are a part of our sample.

The period of study is from April 2004 to March 2012 however data period varies across commodities owing to their late introduction on trading exchanges and the fact that some agricultural commodities were banned from trading for a certain period to curb speculative impacts which according to policy makers could have triggered high inflation. The data comprises of daily closing spot and futures prices of the sample commodities. Natural logarithm of daily prices is taken to minimize the heteroscedasticity in data. The daily spot returns are constructed from the spot price data as $\log \left(P_{\mathrm{s}, \mathrm{t}} / P_{\mathrm{s}, \mathrm{t}-1}\right)$, where $P_{\mathrm{s}, \mathrm{t}}$ is the spot price at time t. These commodities are applied to examine the aggregate behaviour of commodities with regards to destabilisation effects. The description of data is described in Table 1:

Table 1. Description of agricultural commodities taken in sample

\begin{tabular}{|c|c|c|}
\hline AGRI COMMODITIES & Data-Periods & Future Market (source) \\
\hline GUARSEED & $13-04-2004$ to $10 / 20 / 2012$ & NCDEX \\
\hline TURMERIC, & $13-04-2004$ to $10 / 20 / 2012$ & NCDEX \\
\hline SOYBEAN & $1-09-2004$ to $10 / 20 / 2012$ & NCDEX \\
\hline BLACK-PEPPER & $13-04-2004$ to $9 / 19 / 2012$ & NCDEX \\
\hline BARLEY & $13-04-2004$ to $9 / 19 / 2012$ & NCDEX \\
\hline MAIZE & $1-5-2005$ to $9 / 19 / 2012$ & NCDEX \\
\hline CASTOR SEED & $21-9-2004$ to $9 / 19 / 2012$ & NCDEX \\
\hline
\end{tabular}

The table shows the sample commodities used in the study. The period of study is from April 2004-to March 2012 however the data period varies across commodities. The sample consists of five agricultural commodities which are traded on NCDEX.

Given the nature of the problem and the quantum of data, we first study the data properties from an econometric perspective. The time series stationarity of sample price series has been tested using Augmented Dickey Fuller (ADF) 1981. The ADF test uses the existence of a unit root as the null hypothesis. To double check the robustness of the results, Phillips and Perron (1988) test of stationarity has also been performed for the series. In this work, the issues have been addressed through both contemporaneous as well as dynamic relationship between spot 
price volatility and futures trading activity. Following Bessembinder \& Seguin, (1992), we decompose the futures volume into expected and unexpected components using Hodrick-Prescott filter (HP filter).

To clearly understand the destabilization effect, the relationship of the unexpected liquidity of futures market is done with Unexpected volatility of spot market returns which is estimated by taking the residuals of the GARCH model.Firstly we test that whether futures trading volume unexpected) affect the conditional spot price volatility contemporaneously .The contemporaneous relationship is tested by GARCH model. Then Granger causality Test is done to understand the causal relationship of futures and spot i.e. lead lag i.e. to have a clear understanding whether futures trading is leading to rise in spot price volatility or vice-versa.

\section{The Hodrick-Prescott filter (HP filter)}

The paper uses HP filter to decompose the study series into expected and unexpected components. Like any agricultural product, the commodities under our study face seasonal/cyclical fluctuations. The Hodrick-Prescott Filter methodology was used to filter out the transitory components of the fundamental series. This is used to decompose the variables in the prices into trend and stationary components, which are respectively induced by real and nominal shocks. The technique suggests that the real shocks cause permanent changes in prices whereas nominal shocks only cause temporary effects on the real prices. It is thus supposed that if one can observe the values of a series yt through $\mathrm{yT}$ and it is possible to decompose the series into a trend $(\mu \mathrm{t})$ and a stationary component $\mathrm{yt}$ - $\mu \mathrm{t}$,one can solve a minimisation problem for the deviation of yt from $\mu \mathrm{t}$.

The HP filter is a tool and provides an estimate of the unobserved variable (trend) as the solution to the following minimization problem (Basdevant, 2003):

$$
\underset{\left\{Z^{*}\right\}}{\operatorname{Min}}: \sum_{t=1}^{T} \frac{1}{\sigma_{0}^{2}}\left(Z_{t}-Z_{t}^{*}\right)^{2}+\frac{1}{\sigma_{1}^{2}}\left(\Delta^{2} Z_{t}^{*}\right)^{2}
$$

Where $Z$ is the observed variable, $Z^{*}$ is the unobserved variable being filtered, $\sigma_{0}^{2}$ is the variance of the cyclical component $Z_{t}-Z_{t}^{*} . \sigma_{1}^{2}$ shows the variance of the growth rate of the trend component. This problem is of course invariant to a homothetic transformation, therefore what matters is the ratio $\lambda=\frac{\sigma_{0}^{2}}{\sigma_{1}^{2}}$. Hodrick and Prescott suggest some parameterization of $\lambda$ depending on the frequency of data.

However, the cyclical component is derived by applying HP filter such as:

$$
C=\left(Z_{t}-Z_{t}^{*}\right), \quad t=1,2 \ldots \ldots \ldots \ldots, T
$$




\section{Macrothink}

Asian Journal of Finance \& Accounting

ISSN 1946-052X 2012, Vol. 4, No. 2

Unexpected variable which was made by decomposing the trading volume is ready by filtering the data using this test.

\section{GARCH Model}

\section{The GARCH $(1,1)$ Model}

We begin with the simplest GARCH $(1,1)$ specification:

$$
\begin{gathered}
Y_{t}=X_{t}^{\prime} \theta+\varepsilon_{t} \\
\sigma_{t}^{2}=\omega+\alpha \varepsilon_{t-1}^{2}+\beta \sigma_{t-1}^{2}
\end{gathered}
$$

$\mathrm{n}$ which the mean equation given in (a) is written as a function of exogenous variables with an error term. Since $\sigma_{t}^{2}$ is the one-period ahead forecast variance based on past information, it is called the conditional variance. The conditional variance equation specified in (b) is a function of three terms:

1) A constant term $\omega$

2) News about volatility from the previous period, measured as the lag of the squared residual from the mean equation $\varepsilon_{t-1}^{2}$ (the $\mathrm{ARCH}$ term).

3) Last period's forecast variance $\sigma_{t-1}^{2}$ (the GARCH term).

The $(1,1)$ in GARCH $(1,1)$ refers to the presence of a first-order autoregressive GARCH term (the first term in parentheses) and a first-order moving average $\mathrm{ARCH}$ term (the second term in parentheses). An ordinary ARCH model is a special case of a GARCH specification in which there are no lagged forecast variances in the conditional variance equation, a $\operatorname{GARCH}(0,1)$.

There are two equivalent representations of the variance equation that may aid you in interpreting the model:

1) If we recursively substitute for the lagged variance on the right-hand side of Equation (b), we can express the conditional variance as a weighted average of all of the lagged squared residuals:

$$
\sigma_{t}^{2}=\frac{\omega}{1-\beta}+\alpha \sum_{j=1}^{\infty} \beta^{j-1} \varepsilon_{t-j}^{2}
$$

We see that the $\operatorname{GARCH}(1,1)$ variance specification is analogous to the sample variance, but that it down-weights more distant lagged squared errors. 
2) The error in the squared returns is given by $v_{t}^{2}=\varepsilon_{t}^{2}-\sigma_{t}^{2}$. Substituting for the variances in the variance equation and rearranging terms we can write our model in terms of the errors:

$$
\varepsilon_{t}^{2}=\omega+(\alpha+\beta) \varepsilon_{t-1}^{2}+v_{t}-\beta v_{t-1}
$$

Thus, the squared errors follow a heteroscedasitic ARMA $(1,1)$ process. The autoregressive root which governs the persistence of volatility shocks is the sum of $\alpha$ and $\beta$. In many applied settings, this root is very close to unity so that shocks die out rather slowly. The GARCH (q, p) model and the GARCH-M model are other versions of GARCH model. We take the residuals of GARCH model to take this as a measure of spot market volatility. GARCH $11 \mathrm{P}$ Q process is checked from (0-4) process and information is optimized for GARCH 11 model hence our paper model has used this model.

\section{Granger Causality test}

The unexpected component of trading Volume and residuals of GARCH model are tested for causality i.e. Whether liquidity in the futures market is destabilizing the spot market volatility or vice-versa?

\section{Causality Testing}

A series $\mathrm{x}$ may be said to cause $\mathrm{y}$ if and only if the expectation of $\mathrm{y}$ given that $\mathrm{x}$ is different from the unconditional expectation of $y$.

$$
E\left(y \mid y_{t-x}, X_{t-k}\right) \neq E\left(y \mid y_{t-k}\right)
$$

For a theory, $x \rightarrow y$, find a $\mathrm{z}$ such we derive on a causal sequence $\mathrm{x} \rightarrow \mathrm{z} \rightarrow \mathrm{y}$. If $\mathrm{z}$ explains the connection the $x-y$ connection, it follows that controlling $z$ will eliminate all further associations. Thus, for

$y=\beta_{0}+\beta_{1} x+\beta_{2} x+\varepsilon, \beta_{1}$ would be zero.

Testing if $\beta_{1}=0$, then we test the causal theory of $\mathrm{y}$.

\section{Analysis and Interpretations of Results}

The results of stationarity tests are given in Table 2. It confirms non stationarity of commodity price and Trading Volume data; hence we repeat stationarity tests on return series (estimated as first difference of log prices and Trading Volume) which are also provided in Table 2. The table describes the sample price series and Trading Volume that have been tested using Augmented Dickey Fuller (ADF) 1981. The ADF test uses the existence of a unit root as the null hypothesis. To double check the robustness of the results, Phillips and Perron (1988) test of stationarity has also been performed for the price series and Trading Volumes and then both the test are performed on return series Panel A,B respectively. The sample return series and 
Trading Volume exhibit stationarity thus conforming that spot and future commodity prices and Trading Volume are integrated to the first order.

Table 2 .

\begin{tabular}{|c|c|c|c|c|}
\hline \multirow[b]{2}{*}{ COMMODITIES } & \multirow{2}{*}{$\begin{array}{l}\text { A-Price- Series } \\
\text { ADF Test }\end{array}$} & \multirow{2}{*}{ Phillips-Perron Test } & \multicolumn{2}{|c|}{ B-Inference On Return Series Integration I (I) } \\
\hline & & & ADF Test & Phillips-Perron Test \\
\hline & t-statistics & t-statistics & t-statistics & t-statistics \\
\hline \multicolumn{5}{|l|}{ GUARSEED } \\
\hline (a)(Trading Volume) & -2.09 & -2.10 & $-36.5 * *$ & $-36.51 * *$ \\
\hline (b)future-price & -2.19 & -2.17 & $-36.5 * *$ & $-36.51 * *$ \\
\hline (c)spot-price & -1.1 & -1.3 & $-24.9 * *$ & $-42.18 * *$ \\
\hline TURMERIC & -2.37 & -2.27 & $-34.22 * *$ & $-32.12 * *$ \\
\hline \multicolumn{5}{|l|}{ (a)(Trading Volume) } \\
\hline (b)future-price & -2.67 & -2.67 & $-36.33 * *$ & $-36.33 * *$ \\
\hline (c)spot-price & 1.85 & 3.09 & $-8.36 * *$ & $-36.84 * *$ \\
\hline \multicolumn{5}{|l|}{ SOYBEAN } \\
\hline (a)Trading Volume) & -0.47 & -0.49 & $-25.62 * *$ & $-23.23 * *$ \\
\hline (a)future-price & -0.57 & -0.53 & $-26.75 * *$ & $-26.74 * *$ \\
\hline (b)spot-price & -0.42 & -0.42 & $-27.76 * *$ & $-27.71 * *$ \\
\hline \multicolumn{5}{|l|}{ BLACK PEPPER } \\
\hline (a)Trading Volume & 0.91 & 0.72 & $-33.84 * *$ & $-32.34 * *$ \\
\hline (a)future-price & 0.81 & 0.69 & $-34.95 * *$ & $-34.95 * *$ \\
\hline (b)spot-price & -0.1 & -0.16 & $-36.44 * *$ & $-36.45 * *$ \\
\hline \multicolumn{5}{|l|}{ BARLEY } \\
\hline (a)Trading Volume & 0.34 & 0.3 & $-41.36 * *$ & $-41.35 * *$ \\
\hline (a)future-price & 0.36 & 0.4 & $-42.47 * *$ & $-42.47 * *$ \\
\hline (b)spot-price & -0.35 & -0.32 & $-43.76 * *$ & $-43.76 * *$ \\
\hline \multicolumn{5}{|l|}{ MAIZE } \\
\hline (a)Trading Volume & 0.33 & 0.3 & $-41.36 * *$ & $-41.32 * *$ \\
\hline (a)future-price & 0.32 & 0.3 & $-33.95 * *$ & $-33.74 * *$ \\
\hline (b)spot-price & -0.33 & -0.36 & $-35.44 * *$ & $-37.43 * *$ \\
\hline \multicolumn{5}{|l|}{ CASTOR SEED } \\
\hline (a)Trading Volume & 0.71 & 0.57 & $-39.75 * *$ & $-37.95 * *$ \\
\hline (a)future-price & 0.71 & 0.57 & $-39.75 * *$ & $-37.95 * *$ \\
\hline (b)spot-price & -0.2 & -0.75 & $-36.34 * *$ & $-39.45 * *$ \\
\hline
\end{tabular}

\section{Destabilisation Effect}

To understand the destabilization effect which is a relationship of futures liquidity and spot market volatility, the data is filtered using Hedrick Prescott (HP) filter and unexpected variable (unexpected liquidity) is formulated by subtracting Hp Trend variable which was generated when data was filtered from trading volume. Unexpected volatility of spot market returns was estimated by taking the residuals of Bollerslev (1986) generalize autoregressive 
conditional heteroscedasticity $(\mathrm{GARCH})$ model and then we perform the causality tests between spot volatility and unexpected trading volume, we choose the appropriate lag length using AIC (Akaike information criterion) lagged length of each variable in this study consistently, to have a clear understanding whether futures trading are leading to rise in spot price volatility or vice-versa. The next step is to conduct diagnostic checking on the selected model. While the volatility model later will be used in a number of different variation, the

diagnostic checking will here be conducted on the core $\operatorname{GARCH}(1,1)$ model, to see if it is a reasonable fit for the return data .Later in the empirical analysis goodness-of-fit estimates such as LM test and Ljung-Box Q test will be conducted to evaluate the various models ability to fit the data. The diagnostic checking tests are conducted on the estimated standardized residuals, which should have the properties of classical regression models, i.e. they should be white noise. This implies that they should display no autocorrelation, no conditional heteroscedasticity and their distribution should be equivalent to the error distribution used in the model estimation. The model is corrected using the parameters of goodness of fit but are not reported because of space. Applying this methodology on seven agricultural commodities the following results were revealed.

In case of Guarseed, Turmeric, Soybean, Maize and Castor Seed the study confirms that Futures market liquidity (based on trading volume) tends to drive spot market volatility i.e. stating destabilizing effect. This evidence is consistent with Bessembinder and Seguin (1992). Our results indicate that the commodity spot volatility is significantly impacted by the unexpected futures trading volume for five agricultural commodities out of total 7 taken under study, excluding Pepper and Barley see Table III. This may be because of high transaction costs or the friction associated with the spot market and also in India spot market is slow in assimilating information coming from futures markets thereby confirming the dominant role of futures market. The finding of destabilizing effect of futures trading volume on spot volatility is in line with the large number of empirical studies who also report positive relationship between futures trading volume and spot volatility (Pashigian, 1986; Weaver and Banerjee, 1990; Chatrath, Ramchander and Song (1996) on currency futures and Yang et al., 2005), but contradictory to the findings of Darrat and Rahman (1995) on S\&P 500 index futures.

The results may be explained by the fact that spot market is not well organized as it is not electronically traded and hence lacks transparency. Thus futures trading activity may have inflationary implications on spot prices, which should worry the regulators. The results thus, underline the need for creating organized spot market for agri-commodities. In case of Black pepper reversed destabilization effect is observed. Spot market volatility tends to affect futures market trading activity, measured by trading volumes liquidity, indicating a strong speculative interest in the market the results may be explained by the fact that spot market is not well-organized and lacks transparency. In case of Barley the study confirms that Futures market liquidity (based on trading volume) does not affect spot market volatility. It implies that the spot market is well developed for this commodity. No price destabilization effect is observed and there seems to be no relationship between futures market trading activity and spot market volatility. 
Table 3. Destabilizing / Stabilizing Effects Of Futures Trading On Spot Price Volatility

\begin{tabular}{|c|c|c|}
\hline GUARSEED MARKET & F-Statistic & Prob. \\
\hline Spot volatility on unexpected futures liquidity & 0.65549 & 0.7305 \\
\hline Unexpected-liquidity on Spot-Volatility & $6.91660^{* *}$ & $2 \mathrm{E}-08$ \\
\hline \multicolumn{3}{|l|}{ TURMERIC MARKET } \\
\hline Spot volatility on unexpected futures liquidity & 0.09101 & 0.7632 \\
\hline Unexpected-liquidity on Spot-Volatility & $8.42109 * *$ & 0.0041 \\
\hline \multicolumn{3}{|l|}{ SOYBEAN MARKET } \\
\hline Spot volatility on unexpected futures liquidity & 1.14057 & 0.3316 \\
\hline Unexpected-liquidity on Spot-Volatility & $2.06633 * *$ & 0.0271 \\
\hline \multicolumn{3}{|l|}{ PEPPER MARKET } \\
\hline Spot volatility on unexpected futures liquidity & $3.04891 * *$ & 0.0041 \\
\hline Unexpected-liquidity on Spot-Volatility & 0.87045 & 0.5302 \\
\hline \multicolumn{3}{|l|}{ BARLEY MARKET } \\
\hline Spot volatility on unexpected futures liquidity & 0.0708 & 0.7904 \\
\hline Unexpected-liquidity on Spot-Volatility & 1.0869 & 0.2981 \\
\hline MAIZE MARKET & F-Statistic & Prob. \\
\hline Spot volatility on unexpected futures liquidity & 1.24057 & 0.4316 \\
\hline Unexpected-liquidity on Spot-Volatility & $3.06633 * *$ & 0.0121 \\
\hline CASTOR SEED MARKET & F-Statistic & Prob. \\
\hline Spot volatility on unexpected futures liquidity & 0.08101 & 0.6632 \\
\hline Unexpected-liquidity on Spot-Volatility & $7.32109 * *$ & 0.0031 \\
\hline
\end{tabular}

\section{Summary Conclusion and Policy Suggestions}

Commodity futures trading in India has been a subject of burning debate amongst policy makers and academia. Strong media attention has also been caught in the past few years; due to uncertainties relating to price manipulations and the general belief that possible speculative trading in futures market may have destabilised spot prices of underlying commodities. Proponents of commodity futures derivative trading emphasize that these markets help in risk management platforms for hedgers such as farmers, industrial units, exporters, importers, etc., who have price risk exposures and help in price discovery of underlying physical commodities .To understand the destabilization effect which is a relationship of futures liquidity and spot market volatility, the data is filtered using Hedrick Prescott (HP) filter and unexpected variable (unexpected liquidity) is formulated by subtracting Hp Trend variable which was generated when data was filtered from trading volume. Unexpected volatility of spot market returns was estimated by taking the residuals of Bollerslev (1986) generalize 
autoregressive conditional heteroscedasticity (GARCH) model and then we perform the causality tests between spot volatility and unexpected trading volume, we choose the appropriate lag length using AIC (Akaike information criterion) lagged length of each variable in this study consistently, to have a clear understanding whether futures trading are leading to rise in spot price volatility or vice-versa. Applying this methodology on seven agricultural commodities the following results were revealed.In case of Guarseed, Turmeric, Soybean, Maize and Castor Seed the study confirms that Futures market liquidity (based on trading volume) tends to drive spot market volatility i.e. stating destabilizing effect. This evidence is consistent with Bessembinder and Seguin (1992).As futures and spot markets are interlinked, any information shock should affect both the markets. Results of the lead lag relationship between spot price volatility and futures trading activity (unexpected) suggest that in most of the commodities the unexpected futures trading volume causes spot price volatility. The results is confirmed by Granger causality test, indicating that the commodity spot volatility is significantly impacted by the unexpected futures trading volume for five agricultural commodities out of total 7 taken under study, excluding Pepper and Barley. This may be because of low rate of information dissemination coming from futures market, high transaction costs or the friction associated with the spot market. The finding of destabilizing effect of futures trading volume on spot volatility is in line with the large number of empirical studies who also report positive relationship between futures trading volume and spot volatility (Pashigian, 1986; Weaver and Banerjee, 1990; Chatrath, Ramchander and Song (1996) on currency futures and Yang et al., 2005), but contradictory to the findings of Darrat and Rahman (1995) on S\&P 500 index futures. The results may be explained by the fact that spot market is not well organized as it is not electronically traded and hence lacks transparency. Thus futures trading activity may have inflationary implications on spot prices, which should worry the regulators. The results thus, underline the need for creating organized spot market for agri-commodities. In case of Black pepper reversed destabilization effect is observed. Spot market volatility tends to affect futures market trading activity, measured by trading volumes liquidity, indicating a strong speculative interest in the market the results may be explained by the fact that spot market is not well-organized and lacks transparency. In case of Barley the study confirms that Futures market liquidity (based on trading volume) does not affect spot market volatility. It implies that the spot market is well developed for this commodity. No price destabilization effect is observed and there seems to be no relationship between futures market trading activity and spot market volatility.

\section{Policy Suggestions}

The policy suggestions include those relating to un-notice abrasions in market behaviour and measures that can strengthen the commodity futures trading in India.

- The commodity exchanges must strengthen their surveillance system for early detection of anomalous trading behaviour for all commodities. In case there is any anomalous behaviour it must be put under active monitoring on continuous basis.

- The government should pass the Forward Contract Regulation Amendment (FCRA) Bill 2010 at the earliest, which shall provide administrative and financial autonomy to Forwards 
Market Commission (FMC) and give it adequate powers to regulate commodity market and penalise any insider trading and price manipulations.

- The Government must encourage futures trading in these markets as they play an important role in price discovery and price risk management. Suspension of trading is a not a solution and may actually harm the process of market development. Rather, an efficient surveillance system must be set in place, to minimize probability of price distortions.

- Given the nascent nature of commodities derivatives market in India, the Government must support these trading platforms with by providing fiscal incentives, sound regulatory environment, infrastructure facilities and broad basing the investor list. Commodity market has economy wide implications on issues relating to inflation, infrastructure development, wealth creation, employment generation, etc. Hence, the Government support shall lead to market growth and overall economic development.

- Well-organized spot markets must be developed, ensuring transparency and trading efficiency. Electronically traded spot exchanges must be developed and warehousing, testing labs as well as other eco-system linkages must be established.

- Institutional investors' participation must be allowed so that these markets achieve higher trading liquidity. Innovative derivative instruments such as commodity options must be introduced to attract higher trading volumes and provide a better risk management alternative.

- $\quad$ FMC must come out with a long term investor education strategy. Investor education is the best way to empower investors and hence the issue needs special attention. A well-informed investor's base shall create greater trading liquidity and help in avoiding price manipulations.

- We recommend that a detailed analysis using high frequency data must be performed for a wide range of agri-commodities in order for the government and the market regulator to arrive at long-term policy conclusion.

\section{References}

Abdullah, D.A., \& Rangazas, P.C. (1988). Money and the Business Cycle: Another Look. Review of Economics and Statistics, 70, 680-85. http://dx.doi.org/10.2307/1935833

Antoniou, A., \& Ergul, N. (1997). Market efficiency, thin trading and non-linear behaviour: evidence from an emerging market. European Financial Management, 3, 175-90. http://dx.doi.org/10.1111/1468-036X.00038

Antoniou, A., \& Foster, A.J. (1992). The effect of futures trading on spot price volatility: evidence for Brent crude oil using GARCH. Journal of Business Finance and Accounting, 19, 473-484. http://dx.doi.org/10.1111/j.1468-5957.1992.tb00639.x 
Antoniou, A., Holmes, P., \& Priestley, R. (1998). The effects of stock index futures trading on stock index volatility: An analysis of the asymmetric response of volatility to news.

Journal of Futures Markets, 18, 151-166.

http://dx.doi.org/10.1002/(SICI)1096-9934(199804)18:2<151::AID-FUT2>3.0.CO;2-1

Bakaert, G., \& Harvey, C. R. (1997). Emerging equity market volatility. Journal of Financial Economics, 43, 29-77. http://dx.doi.org/10.1016/S0304-405X(96)00889-6

Bessembinder, H., \& Seguin, P.J., (1992). Futures trading activity and stock price volatility. Journal of Finance, 47, 2015-2034. http://dx.doi.org/10.1111/j.1540-6261.1992.tb04695.x

Bessembinder, H., \& Seguin, P. J. (1993). Price volatility, trading volume, and market depth: evidence from futures markets. Journal of Financial and Quantitative Analysis, 28, 21-39. http://dx.doi.org/10.2307/2331149

Board, J., Sandmann, G., \& Sutcliffe, C. (2001). The effect of futures market volume on spot market volatility. Journal of Business finance and accounting, 28, 799819.

http://dx.doi.org/10.1111/1468-5957.00394

Brown-Hruska, S., \& Kuserk, G. (1995). Volatility, volume and the notion of balance in the S\&P 500 cash and futures markets. Journal of Futures Markets, 15, 677-689.

http://dx.doi.org/10.1002/fut.3990150606

Campbell, J. Y., Grossman, S. J., \& Wang, J. (1993). Trading volume and serial correlation in stock returns. Quarterly Journal of Economics, 108, 905-39.

http://dx.doi.org/10.2307/2118454

Carter, C. A. (1989). Arbitrage opportunities between thin and liquid futures markets. The Journal of Futures Markets, 9, 347-353. http://dx.doi.org/10.1002/fut.3990090408

Chang, E. C., Cheng, J. W., \& Pinegar, J. M. (1999). Does future trading increase stock market volatility? The case of the Nikkei stock index futures markets. Journal of Banking and Finance, 23, 727-753. http://dx.doi.org/10.1016/S0378-4266(98)00069-7

Chang, E., Chou, R.Y., \& Nelling, E.F. (2000). Market volatility and the demand for hedging in Stock Index Futures. The Journal of Futures Markets, 20, 105-125.

http://dx.doi.org/10.1002/(SICI)1096-9934(200002)20:2<105::AID-FUT1>3.0.CO;2-Q

Chatrath, A., Ramchander, S., \& Song, F. (1996). The role of futures trading activity in exchange rate volatility. The Journal of Futures Markets, 16, 561-584.

http://dx.doi.org/10.1002/(SICI)1096-9934(199608)16:5<561::AID-FUT4>3.0.CO;2-E

Chen, N., Cuny, C.J., \& Haugen, R. A. (1995), Stock Volatility and the Levels of the Basis and Open Interest in Futures Contracts'. Journal of Finance, 50, 281-300.

http://dx.doi.org/10.2307/2329246

Clifton, E.V. (1985). The currency futures market and interbank foreign exchange trading.

The Journal of Futures Markets, 5, 375-384. http://dx.doi.org/10.1002/fut.3990050308 
Cox, C. C. (1976). Futures trading and market information. Journal of Political Economy, 84, 1215-1237. http://dx.doi.org/10.1086/260509

Damodaran, A. (1990). Index futures and stock market volatility. Review of Futures Markets, 9, 442-457.

Danthine, J. (1978), Information, futures prices, and stabilizing speculation. Journal of Economic Theory, 17, 79-98. http://dx.doi.org/10.1016/0022-0531(78)90124-2

Darrat, A.F., \& Rahman, S. (1995). Has Futures Trading Activity Caused Stock Price Volatility? Journal of Futures Markets, 15, 537-57.

http://dx.doi.org/10.1002/fut.3990150503

Darrat, A.F., Rahman, S., \& Zhong, M. (2002). On the Role of Futures Trading in Cash Market Fluctuations: Perpetrator of Volatility or Victim of Regret? Journal of Financial Research, 25, 431-44. http://dx.doi.org/10.1111/1475-6803.00028

Figlewski, S. (1981). Futures trading and volatility in the GNMA market. Journal of Finance, 36, 445-456. http://dx.doi.org/10.2307/2327030

Froot, K. A., \& Perold, A. F. (1991). New trading practices and short-run market efficiency, Working paper, MIT.

Fung, H-G., \& Patterson, G. A. (1998). The dynamic relationship of volatility, volume, and market depth in currency futures markets. Journal of International Financial Markets, Institutions and Money, 9, 33-59. http://dx.doi.org/10.1016/S1042-4431(98)00035-3

Grammatikos, T., \& Saunders, A. (1986). Futures price variability: a test of maturity and volume effects. Journal of Business, 59, 319-330. http://dx.doi.org/10.1086/296330

Gulen, H., \& Mayhew, S. (2000). Stock index futures trading and volatility in international equity markets. The Journal of Futures Markets, 20, 661-685.

http://dx.doi.org/10.1002/1096-9934(200008)20:7<661::AID-FUT3>3.0.CO;2-R

Harris, L. (1989). S\&P 500 cash stock price volatilities. Journal of Finance, 44, 1155-1175. http://dx.doi.org/10.1111/j.1540-6261.1989.tb02648.x

Kamara, A. (1982), Issues in Futures Markets: A Survey. Journal of Futures Markets, 2, 261-94. http://dx.doi.org/10.1002/fut.3990020306

Kim, J. (2005). An investigation of the relationship between bond market volatility and trading activities: Korea treasury bond futures market. Applied Financial Economics Letters, 1, 25-29. http://dx.doi.org/10.1080/1744654042000306004

Kim, M., Kim, G. R., \& Kim, M. (2004). Stock market volatility and trading activities in the KOSPI 200 derivatives markets. Applied Economics Letters, 11, 49-53. http://dx.doi.org/10.1080/1350485042000187462

Kyle, A. S. (1985). Continuous auctions and insider trading. Econometrica, 53, 1315-1335. http://dx.doi.org/10.2307/1913210 
Kyriacou, K., \& Sarno, L. (1999). The temporal relationship between derivatives trading and spot market volatility in the UK: Empirical analysis and Monte Carlo evidence. Journal of Futures Markets, 19, 245-270.

http://dx.doi.org/10.1002/(SICI)1096-9934(199905)19:3<245::AID-FUT1>3.0.CO;2-J

Lamoureux, C.G., \& Lastrapes, W.D. (1990). Heteroskedasticity in stock return data: Volume versus GARCH effects. Journal of Finance, 45, 221-229.

http://dx.doi.org/10.1111/j.1540-6261.1990.tb05088.x

Lee, S. B., \& Ohk, k. Y. (1992). Stock index futures listing; and structural changes in time-varying volatility. Journal of Futures .Markets, 12.493-509.

Lockwood, L. L., \& Linn, S. C. (1990). An examination of stock market return volatility during overnight and intraday periods 1964-1989. Journal of Finance, 45, 591-601. http://dx.doi.org/10.2307/2328672

McCarthy, J., \& Najand, M. (1993). State space modeling of price and volume dependence: evidence from currency futures. The Journal of Futures Markets, 13, 335-344.

http://dx.doi.org/10.1002/fut.3990130402

Morgan C.W. (1999). Futures Markets and Spot Price Volatility: A Case Study. Journal of Agricultural Economics, 50, 247-57. http://dx.doi.org/10.1111/j.1477-9552.1999.tb00811.x

Pashigian, B.P. (1986). The Political Economy of Futures Market Regulation. Journal of Business, 59, 55-84. http://dx.doi.org/10.1086/296339

Santoni, G. J. (1987). Has programmed trading made stock prices more volatile? Federal Reserve Bank of St. Louis Review, 18-29.

Sarwar, G. (2003). The interrelation of price volatility and trading volume of currency options. The Journal of Futures Markets, 23, 681-700. http://dx.doi.org/10.1002/fut.10078

Schwert, G. W. (1990). Stock market volatility. Financial Analysts Journal, 46, 23-34. http://dx.doi.org/10.2469/faj.v46.n3.23

Sen, S. and Paul, M. (2010). Trading In India's Commodity Future Markets; Working Paper, Institute For Studies In Industrial Development

Sims, C. (1972), Money, Income, and Causality. American Economic Review, 62, 540-52.

Sims, C. (1980), Macroeconomics and Reality. Econometrica, 48, 1-48. http://dx.doi.org/10.2307/1912017

Tomek, W. G. (1980). Price behavior on a declining terminal market. American Journal of Agricultural Economics, 62, 434-445. http://dx.doi.org/10.2307/1240198

Tse, Y. (1999). Price discovery and volatility spillovers in the DJIA index and futures market. Journal of Futures markets, 19, 911-930.

http://dx.doi.org/10.1002/(SICI)1096-9934(199912)19:8<911::AID-FUT4>3.3.CO;2-H 


\section{Macrothink}

Asian Journal of Finance \& Accounting ISSN 1946-052X

Weaver, R.D., \& A. Banerjee (1990). Does Futures Trading Destabilize Cash Prices?

Evidence for U.S. Live Beef Cattle. Journal of Futures Markets, 10, 41-60.

http://dx.doi.org/10.1002/fut.3990100105

Yang, J., Balyeat, R. B., \& Leatham, D. J. (2005). Futures Trading Activity and Commodity Cash Price Volatility. Journal of Business Finance \& Accounting, 32, 297-323.

http://dx.doi.org/10.1111/j.0306-686X.2005.00595.x 